\title{
引張側に欠き込みをもつ木質系のはりの曲げ 耐力低下のメカニズムに関する若干の考察
}

一一質構造の新しい設計体系確立のための提案と考察（第 9 報）—

正会員 杉 山 英 男*

\section{$\S 1$ 緒言}

さきに「木質系のはりの曲げ耐力と剛性に及ぼす欠き 込みの影響について(続報)」報告したが1)，この実験で 電気抵抗線式歪計を試験体（通常木材と集成木材の 2 種）にとりつけ，欠き込みをもつ曲げ材のせい方向の歪 度分布 (フックの法則が成立する範囲と考えられるの で，歪度分布は直接応力度分布につながる）を測定した が，その結果は未報告であったので，引張側に久き込み をもつ場合の欠き込み部と欠き込み部に接する非久き込 み部の歪度分布（応力度分布）の測定結果を報告し，そ れを基汇張側㐸きき込みがあるときの曲げ材の終局耐 力低下のメカニズムを理論的に考究してみた。

\section{$\S 2$ 引張側に欠き込みをもつ場合の欠き込み部とそ} の周辺における応力度之歪度の分布状態

欠き込みをもつはりに既報の論文"1) の Fig. 1 (b) に 示すよらな荷重を加えた。この場合の久込み部分およ びその周辺に扔いて，はり断面上の歪度分布を調べるた ぬに, はり上下面と側面に電気抵抗線歪計を貼って測定 を行なった。Photo 1 参照。

ワイヤーダージは，はりの材軸方向と平行に貼られた が, ゲージの示す歪度をゲージ長の中央点位置における 歪度と見做して，比例限曲げモーメント並びにその $1 / 2$ に対する歪度分布（前者は実線, 後者は点線で示す）を 示したものが Fig. 1 および Fig. 2 である。

Fig. 1 は通常木材, Fig. 2 熦成木材に対するもの で，両図とも欠き込みせいがはりせいの $1 / 3$ および $1 / 2$ のときのものである。欠き込みせいがはりせいの $1 / 6$ の 場合の歪度分布は揭載してない。

ワイヤーゲージを貼る位置のパターンは次の 2 通りで 西った (Fig. 1 および Fig. 2 参照)。

(1) ワイヤーダージを貼る断面の位置 3 個所……スパ ン中央断面（欠き込み部の中央）とその点からはり支点 记向って $45 \mathrm{~mm}$ (欠き込み部分) 抢よび $80 \mathrm{~mm}$ (非欠 き込み部分) の断面

(2) ワイヤーゲージを貼る断面の位置 4 個所……ス

* 明治大学教授・工博

(昭和 47 年 6 月 16 日本稿受理・討論期限昭和 48 年 2 月末日)

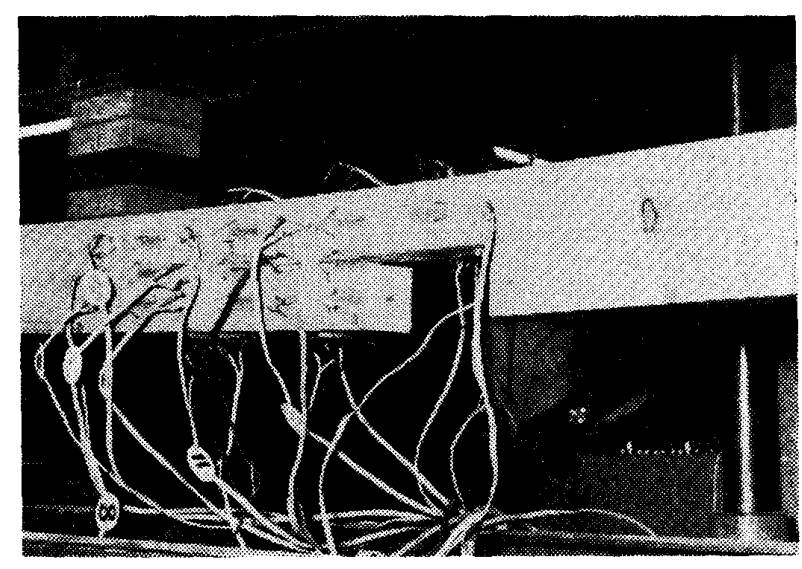

Photo 1 Electric Strain Gauges attached on the specific positions at and near a notch (欠き込み 周辺部のひずみ測定のため取りつけたワイヤー ・ストレイン・ゲージ

ン中央断面（欠き込み部の中央）と，その点からはり支 端に向って $80 \mathrm{~mm}, 205 \mathrm{~mm}, 330 \mathrm{~mm}$ (いずれも非欠き 込み部分) の断面

Fig. 1 および Fig. 2 は引張側に久き込み部をもつ 場合の歪度分布を示しているが，圧縮側に欠き込み部を もつ場合の歪度分布はこれと全く同㑯向で，上下を逆に した図として示される(紙数の都合で図の掲載は控え た)。

Fig. 1 および Fig. 2 は歪度分布を示すものではあ るが，応力度と歪度との間にフックの法則が成立する範 国の測定と考えられるので, 忘力度分布は歪度分布と同 じ形をとると推定される。これら各図を通覧すると，欠 き込み部の応力度分布とこれに接する非欠き込み部の応 力度分布が，通常木材，集成木材の別には関係なく，欠 き込みせいがはりせいの $1 / 2$ の場合は Fig. 3 (a), 1/3 の場合は Fig. 3 (b) の形をとることが共通的傾向とし て指摘できる。

しかし，欠き込みせいがはりせいの $1 / 6$ の場合には， 歪度分布の形がばらばらで共通的な傾向が把握できなか った。Fig. 1 や Fig. 2 のような歪度分布を揭載しな かったのはこのためである。

さて Fig. 1 (a) ( f $)$ 並びに Fig. 2 (a)〜(f) にお いて, 压縮と引張のヤング係数が等しく, かつ応力度は 


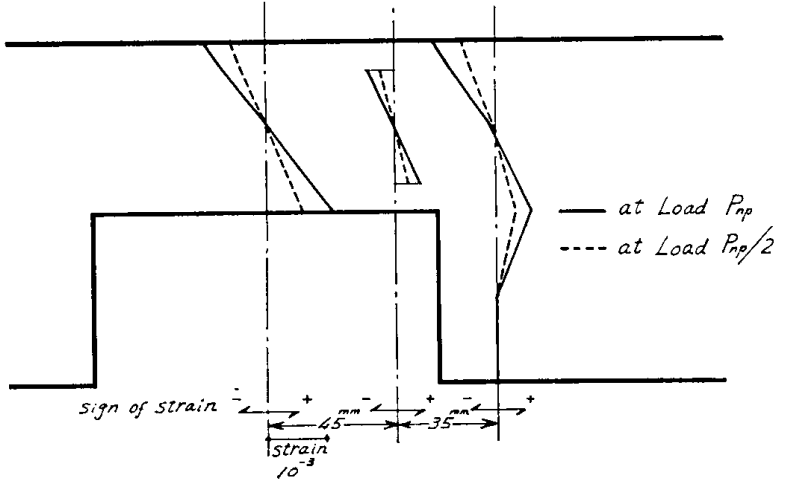

(a) OT-11

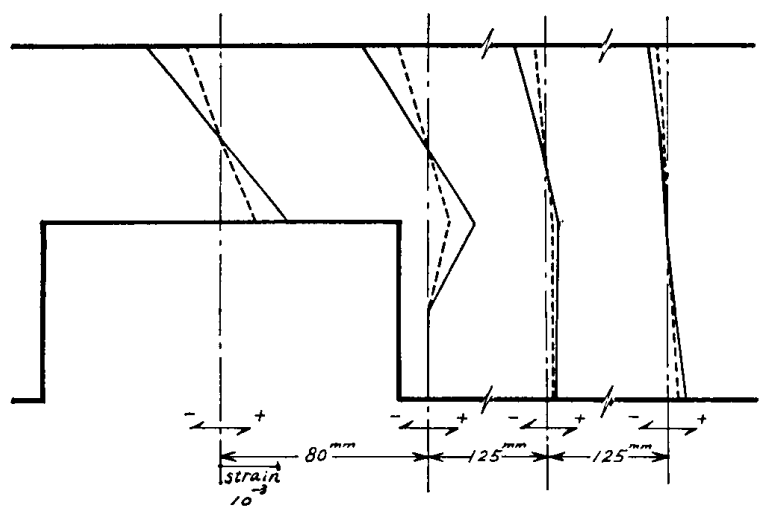

(b) OT-13

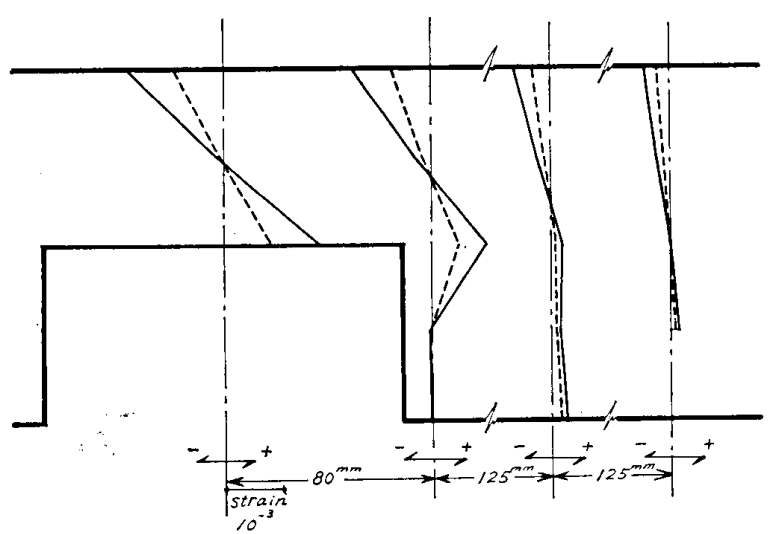

(c) OT-14

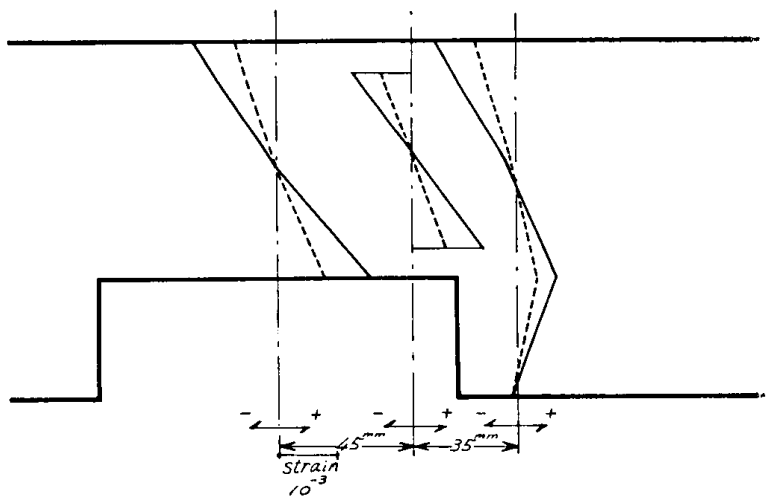

(d) $\mathrm{OT}-21$

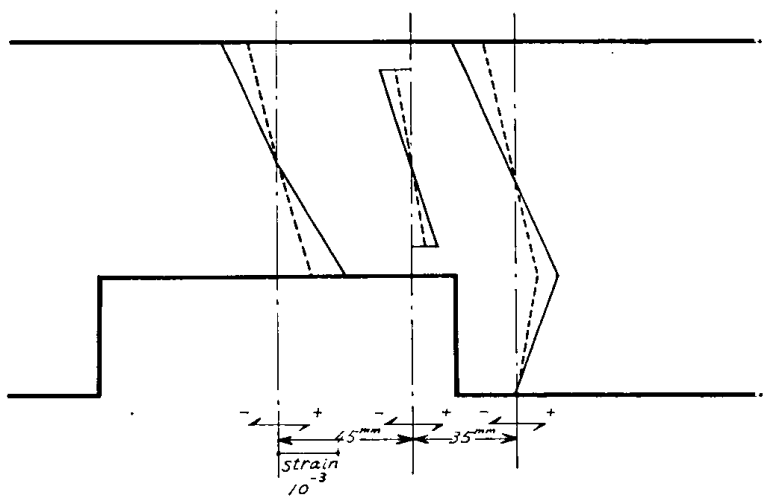

(e) $\mathrm{OT}-22$

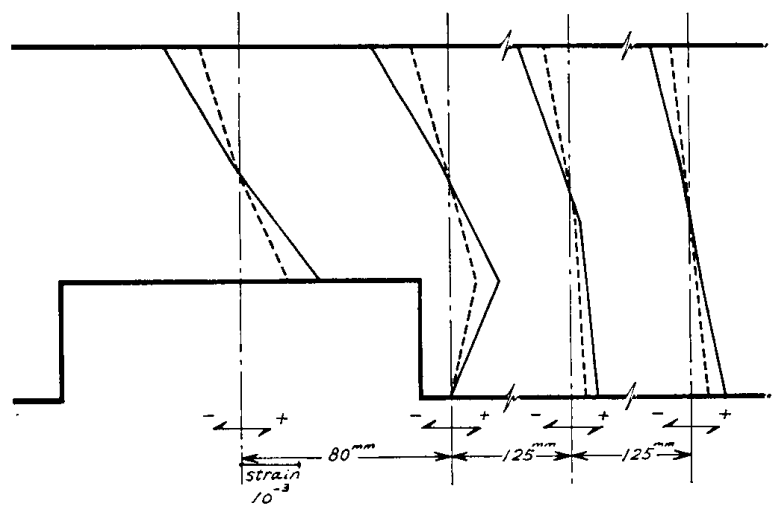

(f) $\mathrm{OT}-24$

Fig. 1 Strain Distribution of Ordinary Timber（通常木材のひずみ度分布）

The meaning of dotted and solid lines is described in $\$ 2$ (点線と実線の意味については本文の §2参照)

歪度に直線的に比例する（フックの法則が成立する）と 仮定してみると，欠き込み部においても非欠き込み部 (Fig. 3 (a)，(b) に打る CDEF 断面, CDF 断面) においても，はり断面上で応力の釣り合い条件がきわめ てよく満足されているのが認められる。そこで, Fig. 3 (a) および (b) について以下で理論的解析を試みてみ ることにする。

\section{§3 欠き込みせいがはりせいの 1/2 の場合の解析}

A. 仮定

(1) 木材の圧縮と引張に対するヤング俰数は等しいと 仮定しこれを $E$ とおく。

(2) 断面は長方形で，幅を $b$ ，せいを $h$ とする。

(3) 曲げ変形後 Fig. 3 (a) の $\mathrm{AB}, \mathrm{CF}$ 両断面はい
ずれも平面保持の法則を満足するものとする。

なおFig. 3 (a) において E 点から下には応力度が発 生せず，かつ $\mathrm{E}$ 点は $\mathrm{D}$ 点と $\mathrm{F}$ 点の中央にある。すなわち $\zeta=(h+d) / 2$ である。

B. AB 断面（欠き込多部）におけるモーメントの釣 合以

欠き込み部の断面係数を $Z_{n}$ とすれば，曲げモーメン ト $M$ を受ける欠き込み部の $\mathrm{AB}$ 断面においてはモー メントの釣合いから次式が導かれる。

$\left.\begin{array}{r}\sigma_{c} Z_{n}=M \\ \text { ただし } \\ Z_{n}=\frac{b d^{2}}{6}\end{array}\right\}$ 


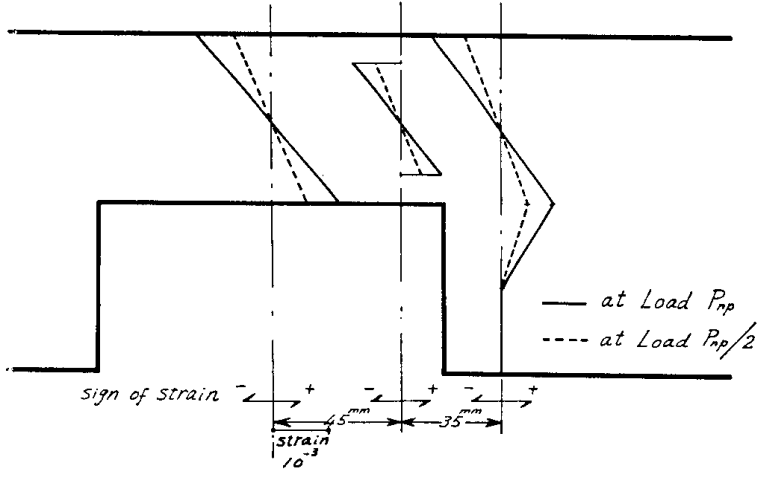

(a) LT-11

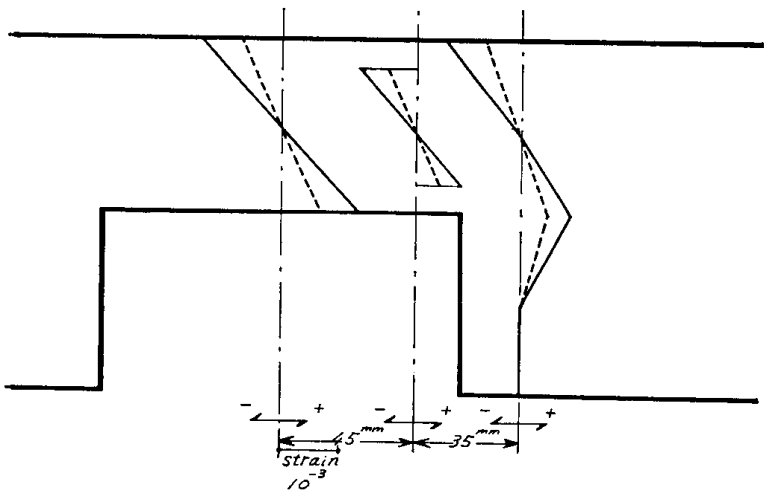

(b) $\mathrm{LT}-12$

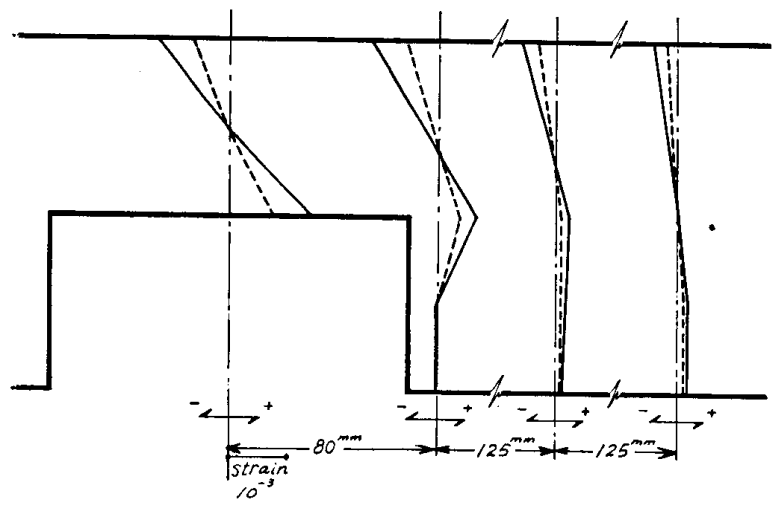

(c) $\mathrm{LT}-13$

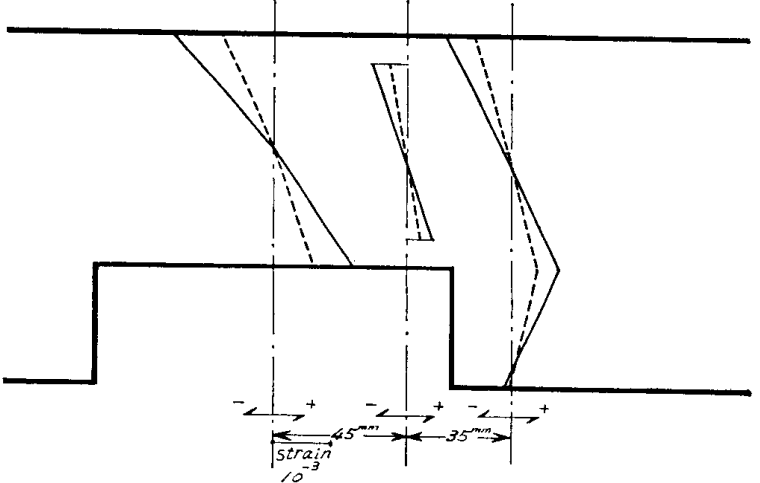

(d) LT-21

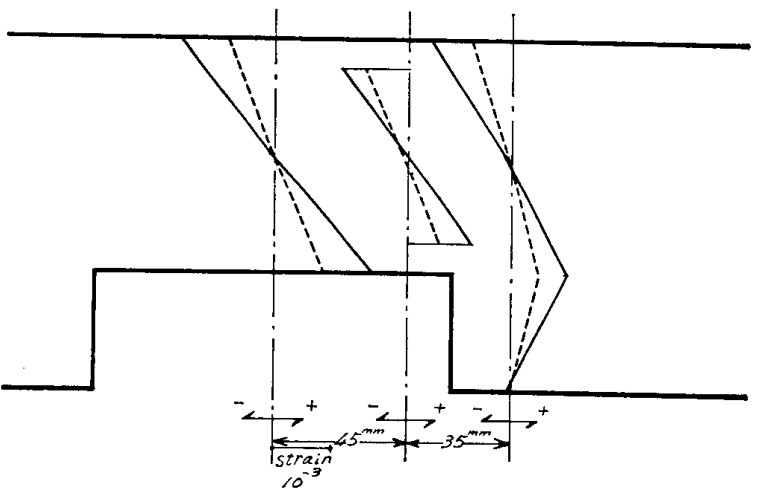

(e) $\mathrm{LT}-22$

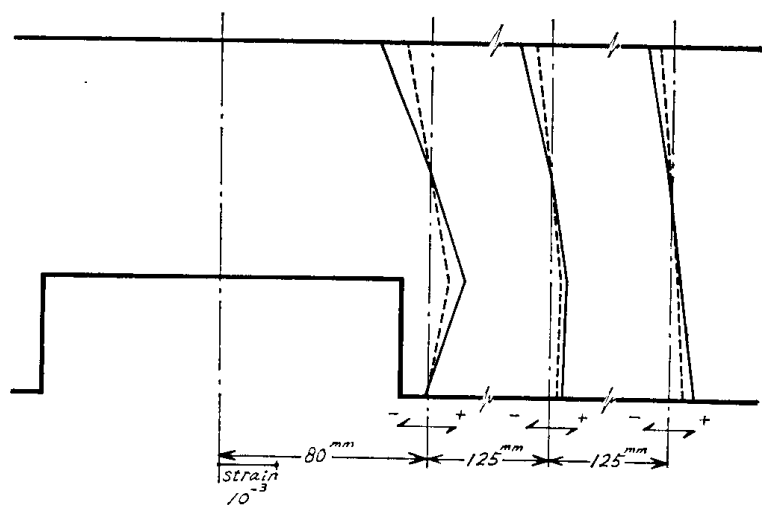

(f) LT-23

Fig. 2 Strain Distribution of Laminated Timber (集成木材のひずみ度分布)

The meaning of dotted and solid lines is described in § 2(点線と実線の意味については本文のミ2参照)

$d:$ 久き込み部分におけるはりせい

C. $\mathrm{CDE}$ 断面（非欠き込み部）に㧍ける軸方向応力 の釣合以

CDE 断面における平面保持の条件から次式が成立す る。各記号については Fig. 3 (a) 参照。

$$
\frac{\sigma_{c}-d \sigma_{c}}{\overline{\sigma_{t}}}=\frac{\frac{d}{2}+d \lambda}{\frac{d}{2}-d \lambda}
$$

$\mathrm{CDE}$ 断面における材軸方向の応力度の釣合いを考え れば

$$
\frac{1}{2} b\left(\sigma_{c}-d \sigma_{c}\right)\left(\frac{d}{2}+d \lambda\right)=\frac{1}{2} b \sigma_{t}
$$

$$
\cdot\left\{h-\left(\frac{d}{2}+d \lambda\right)-\frac{h-d}{2}\right\}
$$

なる関係があり，これを整理すれば

$$
\frac{\sigma_{c}-d \sigma_{c}}{\overline{\sigma_{t}}}=\frac{\frac{h}{2}-d \lambda}{\frac{d}{2}+d \lambda}
$$

式（4）と式（2）から次式が導かれる。

$$
d \lambda=\frac{d(h-d)}{2(3 d+h)}
$$

式（15）を式（14）に代入すれば

$$
\sigma_{c}-d \sigma_{c}=\frac{h+d}{2 d} d \overline{\sigma_{t}}
$$

なる関係が導かれる。 


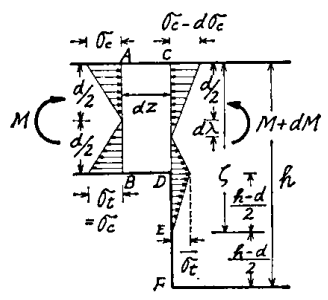

(a) $d / h=1 / 2$

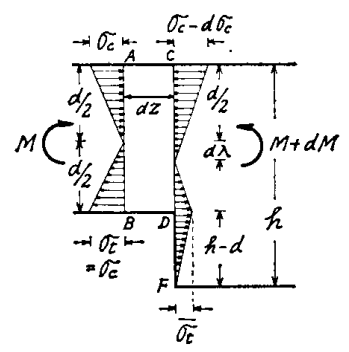

(b)
Fig. 3 Stress Distribution near Notched Portion （欠き込み部およびその周辺における応力 分布)

D. CDE 断面に拉けるモーメントの釣合い

$\mathrm{CDE}$ 断面におけるモーメントの釣合いを考えれば次 式が成立する。

$$
\begin{aligned}
& \frac{1}{3} b\left(\sigma_{c}-d \sigma_{c}\right)\left(\frac{d}{2}+d \lambda\right)^{2}+\frac{1}{3} b \sigma_{t}\left(\frac{d}{2}-d \lambda\right)^{2} \\
& +\frac{1}{2} \cdot b \overline{\sigma_{t}}\left(\frac{h-d}{2}\right)\left(\frac{d}{2}-d \lambda+\frac{h-d}{6}\right) \\
& =M+d M
\end{aligned}
$$

ここに $(M+d M)$ は $\mathrm{CD}$ 断面に衝く曲げモーメン トである。

式（7）に式（6）および式（5）を代入することによ り $\overline{\sigma_{t}}$ が求まる。すなわち

$$
\overline{\sigma_{t}}=\frac{M+d M}{\frac{b}{6}\left(\frac{h+d}{2}\right)^{2}}=\frac{M+d M}{\bar{Z}}
$$

ただし $\bar{Z}=\frac{b}{6}\left(\frac{b+d}{2}\right)^{2}$

式（6）に式（1）と式（8）を代入すれば $d \sigma_{c}$ が次の ように求まる。

$$
d \sigma_{c}=\frac{M}{\left(\frac{b d^{2}}{6}\right)}\left\{1-\frac{d}{\left(\frac{h+d}{2}\right)}\right\}-\frac{d M}{\frac{b d}{6}\left(\frac{h+d}{2}\right)}
$$

本実験の場合のように欠き込み部並びにその周辺が純 曲げ区間に属するときには，式（8）と式（9）において $d M=0$ であるから

$$
\begin{aligned}
& \overline{\sigma_{t}}=M / \bar{Z}=\frac{M}{\frac{b}{6}\left(\frac{h+d}{2}\right)^{2}} \cdots \cdots \cdots \\
& d \sigma_{c}=\frac{M}{\left(\frac{b d^{2}}{6}\right)}\left\{1-\frac{d}{\left(\frac{h+d}{2}\right)}\right\}
\end{aligned}
$$

となる。

次に欠き込み部底面 $\mathrm{D}$ における応力状態を考えてみよ ら。D点は欠き込み部の隅角に位置するから特殊な応力 集中状態にあると考えられるが，ここではそれを無視し Fig. 3 (a) の応力分布だけを土台にして考察を進める。

Fig. 4 (a) に示すように，久き込み部の底面端Dに 接する非久き込み部の微小区間 $\mathrm{DD}^{\prime}$ には，図示のよう に $\mathrm{DD}^{\prime}$ 面に

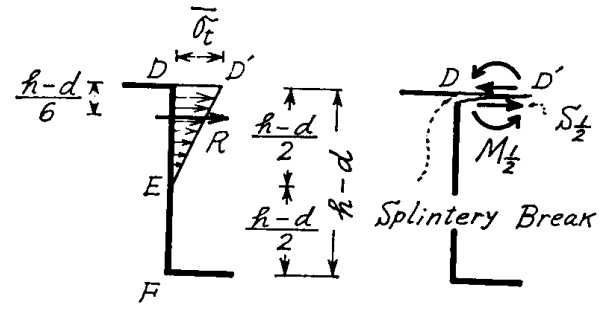

$R:$ Resultant Force

(a)

(b)

Fig. 4 Mechanism of Splintery Break at the End of Notched Portion, when the Depth of Notched Portion is half of the Beam Depth（欠き込双 部底面端における割裂破塤のメカニズム—久 き込み部のせいがはりせいの $1 / 2$ の場合）

$$
\begin{aligned}
\bar{S}_{1 / 2} & =\frac{1}{2} b\left(\frac{h-d}{2}\right) \overline{\sigma_{t}}=\frac{1}{2} b\left(\frac{h-d}{2}\right) \frac{M}{\frac{b}{6}\left(\frac{h+d}{2}\right)^{2}} \\
& =6 \frac{h-d}{(h+d)^{2}} M=\frac{6}{h} \cdot \frac{1-\left(\frac{d}{h}\right)}{\left\{1+\left(\frac{d}{h}\right)\right\}^{2}} M
\end{aligned}
$$

なるせん断力と， $\mathrm{DD}^{\prime}$ 面に対し反時計回りの次の值を: もつモーメント $\bar{M}_{1 / 2}$ が $\mathrm{DD}^{\prime}$ 面に㗢く。

$$
\begin{aligned}
\bar{M}_{1 / 2} & =\frac{6(h-d)}{(h+d)^{2}} M \times \frac{1}{3}\left(\frac{h-d}{2}\right) \\
& =\left(\frac{h-d}{h+d}\right)^{2} M=\left\{\frac{1-\left(\frac{d}{h}\right)}{1+\left(\frac{d}{h}\right)}\right\}^{2} M
\end{aligned}
$$

このモーメントは $\mathrm{DD}^{\prime}$ 面において，これから上の部 分と下の部分とを開離させようとする作用を及ぼし，こ れが $\mathrm{DD}^{\prime}$ 面の割り裂きを誘起するものと考えられる。 以下ではこれを“割裂モーメント”と呼ぶことにす る。

圧縮側に久き込み部が存在する場合には $\mathrm{DD}^{\prime}$ 面に相 当する面にせん断力は㗢くが，この面を割り裂こうとす るモーメントは作用せず，逆化割り裂きを抑えようとす る逆向きのモーメントが作用する。したがって $\mathrm{DD}^{\prime}$ 面 に相当する面には “しわ”が発生するだけで割り裂きは 起きない。圧縮側に欠き込みをもつはりの比例限耐力と 終局耐力が，引張側に欠き込みをもつ場合のそれらょり 大きいのはこのためで，すでに衆知の所である。

\section{§ 4 欠き込みせいがはりせいの $1 / 3$ の場合の解析}

A. 仮 定

この場合にもミ3 A における仮定(1)，(2)並びに(3)の 平面保持の法則がなりたつものとする。

なお Fig. 3 (b) において, DF 間の応力度分布は図 示のように直線である。

B. $\mathrm{AB}$ 断面（欠き込み部）に扔けるモーメントの鈎 合い 
§3の場合と同じようにして式 (1) と同形の次式が導 かれる。

$\left.\begin{array}{c}\sigma_{c} Z_{n}=M \\ \text { ただし } \quad Z_{n}=\frac{b d^{2}}{6}\end{array}\right\}$

ここに $\sigma_{c}$ :Fig. 3 (b) 参照

$d:$ 欠き込み部分におけるはりせい

C. $\mathrm{CDF}$ 断面（非欠き込み部）に抢ける軸方向応力 の釣合い

$\mathrm{CDF}$ 断面における平面保持の法則から式 (2) と同じ 関係が導かれる。記号については Fig. 3 (b) 参照。

CDF 断面に拉ける材軸方向の応力度の釣合いを考え れば

$$
\frac{1}{2} b\left(\sigma_{c}-d \sigma_{c}\right)\left(\frac{d}{2}+d \lambda\right)=\frac{1}{2} b \overline{\sigma_{t}}\left\{h-\left(\frac{d}{2}+d \lambda\right)\right\}
$$

これを整理すれば

$$
\frac{\sigma_{c}-d \sigma_{c}}{\overline{\sigma_{t}}}=\frac{h}{\frac{d}{2}+d \lambda}-1
$$

式（12）に式（2）の関係を代入すれば

$$
d \lambda=\frac{\frac{d}{2}\left(h-\frac{d}{2}\right)}{h+d}
$$

なる関係が求まる。

式（13）を式（12）に代入すれば，次式が導かれる。

$$
\sigma_{c}-d \sigma_{c}=\frac{4 h^{2}-d^{2}}{d(4 h+d)} \overline{\sigma_{t}}
$$

D. CDF 断面におけるモーメントの釣合い

CDF 断面におけるモーメントの釣合いを考えれば， 次式が成立する。

$$
\begin{aligned}
& \frac{1}{2} b\left(\sigma_{c}-d \sigma_{c}\right)\left(\frac{d}{2}+d \lambda\right) \times \frac{2}{3}\left(\frac{d}{2}+d \lambda\right) \\
& +\frac{1}{2} b\left(\frac{d}{2}-d \lambda\right) \overline{\sigma_{t}} \times \frac{2}{3}\left(\frac{d}{2}-d \lambda\right) \\
& +\frac{1}{2} b(h-d) \sigma_{t}\left(\frac{d}{2}-d \lambda+\frac{h-d}{3}\right) \\
& =M+d M
\end{aligned}
$$

上式に式 (13) と式 (14) を代入し計算すれば次の関 係が導かれる。

$$
\overline{\sigma_{t}}=\frac{M+d M}{\frac{b}{6}\left\{h^{2}-\left(\frac{d}{2}\right)^{2}\right\}}
$$

式（14）に式（1）と式（16）を代入すれば $d \sigma_{c}$ は 次のようになる。

$$
\begin{aligned}
& d \sigma_{c}=\frac{M}{\left(\frac{b d^{2}}{6}\right)}\left\{1-\frac{1}{\left(\frac{h}{d}\right)+\frac{1}{4}}\right\}-\frac{d M}{\left(\frac{b d^{2}}{6}\right)} \\
& \frac{1}{\left(\frac{h}{d}\right)+\frac{1}{4}}
\end{aligned}
$$

本実験では久き込み部並びにその周辺は純曲げを受け
る区間に属するから $d M=0$ である。したがって，この 場合式 (15), 式 (16) は次のようになる。

$$
\begin{aligned}
& \overline{\sigma_{t}}=\frac{M}{\frac{b}{6}\left\{h^{2}-\left(\frac{d}{2}\right)^{2}\right\}} \cdots \cdots \cdots \cdots \cdots . . . \\
& d \sigma_{c}=\frac{M}{\left(\frac{b d^{2}}{6}\right)}\left\{1-\frac{1}{\left(\frac{h}{d}\right)+\frac{1}{4}}\right\} .
\end{aligned}
$$

Fig. 5 (b) に示す非欠き込み部に切する微小区間 $\mathrm{DD}^{\prime}$ には, $\mathrm{DD}^{\prime}$ 面に対し

$$
\begin{aligned}
\bar{S}_{1 / 3} & =\frac{1}{2} b(h-d) \overline{\sigma_{t}}=\frac{1}{2} b(h-d) \frac{M}{\frac{b}{6}\left\{h^{2}-\left(\frac{d}{2}\right)^{2}\right\}} \\
& =\frac{3(h-d)}{\left\{h^{2}-\left(\frac{d}{2}\right)^{2}\right\}} \cdot M=\frac{3}{h} \cdot \frac{1-\left(\frac{d}{h}\right)}{1-\frac{1}{4}\left(\frac{d}{h}\right)^{2}} M
\end{aligned}
$$

なるせん断力と, $\mathrm{DD}^{\prime}$ 面に対し反時計回りの次の值を もつ割裂モーメント $\bar{M}_{1 / 3}$ が $\mathrm{DD}^{\prime}$ 面に働く。

$$
\begin{gathered}
\bar{M}_{1 / 3}=\frac{3(h-d)}{\left\{h^{2}-\left(\frac{d}{2}\right)^{2}\right\}} \cdot \frac{h-d}{3} M=\frac{(h-d)^{2}}{\left\{h^{2}-\left(\frac{d}{2}\right)^{2}\right\}} \\
\cdot M=\frac{\left\{1-\left(\frac{d}{h}\right)^{2}\right\}}{\left\{1-\frac{1}{4}\left(\frac{d}{h}\right)^{2}\right\}} M \cdots \cdots \cdots \cdots(19)
\end{gathered}
$$

\section{§5 欠き込みに接する非欠き込み部が割裂により破} 壊するときの応力

§3 および§ 4 において，欠き込み部底面端に接する DD' 面に働くせん断力と割裂モーメントを求める式を 導いたが，それらの式に欠き込み部のはりせいdの值を 代入すれば，次のような結果が導かれる。

（1） 欠き込みせいがはりせいの $1 / 2$ の場合 $(d=h / 2$ のとき):

$$
\left.\begin{array}{l}
\bar{S}_{1 / 2}=\frac{3}{4} \cdot \frac{M}{h}=1.33 \frac{M}{h} \\
\bar{M}_{1 / 2}=\frac{1}{9} M=0.111 M
\end{array}\right\}
$$

（2）欠き込みせいがはりせいの $1 / 3$ の場合 (d=2h/3 のとき) :

$$
\left.\begin{array}{l}
\bar{S}_{1 / 3}=\frac{9}{8} \cdot \frac{M}{h}=1.13 \frac{M}{h} \\
\bar{M}_{1 / 3}=\frac{1}{8} M=0.125 M
\end{array}\right\}
$$

式 (20) と式 (21) を眺めると， $d=1 / 2$ のときの $\mathrm{DD}^{\prime}$ 面に㗢くせん断力と割裂モーメントは， $d=2 h / 3 の$ ときのそれらのそれぞれ 1.18 倍, 0.88 倍で, 両者の間 にはせん断力の上でも割裂モーメントの上でもそれほど の大差注ない(もちろん $\bar{M}_{1 / 2}<\bar{M}_{1 / 3}$ ではあるが)。

引張側に欠き込み部をもつはりが曲げを受けたとき， はりの破壊は $\mathrm{DD}^{\prime}$ 面の水平せん断破壊によって起こる 
が，その原因は $\mathrm{DD}^{\prime}$ 面に働くせん断力 $\bar{S}$ と， $\mathrm{DD}^{\prime}$ 面 を割り裂こうとする割裂モーメント $\bar{M}$ との共働による ものである。上述の所論は弾性域に対する理論である が，欠き込みせいが $1 / 2$ のときと $1 / 3$ のときの間に，せ ん断力と割裂モーメントの上で大差がない（もちろん $\widetilde{M}_{1 / 2}<\widetilde{M}_{1 / 3}$ ではあるが,) ということは, 両者の間に 終局 (破壊) 曲げモーメントの上で大差ないであろうこ とを予想させる。事実既報の 実験1 で 観察されたよう に(既報》の Fig. 3 参照), 欠き込みせいがはりせいの $1 / 2$ の場合の終局曲げモーメントと $1 / 3$ の場合の終局曲 げモーメントとの間には大差が認められない(既報) の Fig. 3 の $M_{n b} / M_{o b}$ の值がほぼ等しいことと同意)。 すなわち，実験結果が理論的におおよそ説明づけられる と言えよう。

な扔, 式 (10), 式 (11) 並びに式 (18), 式 (19) を 跳めると，欠き込みせいがはりせいの $1 / 2$ のときも，1/3 のときも $\mathrm{DD}^{\prime}$ 面に㗢くせん断力 $\bar{S}$ と割裂モーメント $\bar{M}$ は，いずれも $(d / h)^{2}$ と $(d / h)$ の関数で与えられて いる。欠き达み部底面端 $\mathrm{D}$ に招沙る応力集中の影響を考 慮せずに展開した理論であるので今後検討が必要である うが，一応上述の関係は注目すべきものとして指摘して おく。

\section{$\S 6$ 結 論}

これまで述べてきた諸点を要約して結論すれば次の通 りである。

(1) 引張側に欠き込み部をもつ場合の欠き込み部断面 の応力度分布とこれに接する非久き込み部断面の応力度 分布は, 通常木材と集成林材の別には関係なく, 久き込 みせいがはりせいの $1 / 2$ の場合は Fig. 3 (a) のような 形を，1/3 の場合には Fig. 3 (b) のような形をとると 言って大過なからう。この場合 $\mathrm{AB}$ 断面並びに $\mathrm{CF}$ 断 面に扔いて応力の釣合いが満足されているのはもちろん である。なお久き込みせいがはりせいの $1 / 6$ の場合は， 歪度分布の傾向がばらばらで共通的傾向が存在しなかっ た。

(2) 圧縮側に欠き込みをもつ場合の応力度分布, 歪度 分布は，欠き込みせいがはりせいの $1 / 2$ の場合には Fig. 3 (a) と，1/3 の場合には Fig. 3 (b) と同じ形（図と しては上下を逆にしたもの)である。

(3) 欠き込み部底面端の隅角部に㧍ける応力集中を無 視すれば, 引張側欠き込み部底面端に接する非欠き込み 部の割り裂き（Fig. 4 (a) の $\mathrm{DD}^{\prime}$ 面）を誘起する原 因となるせん断力 $\bar{S}$ と割裂モーメント $\bar{M}$ の大きさは

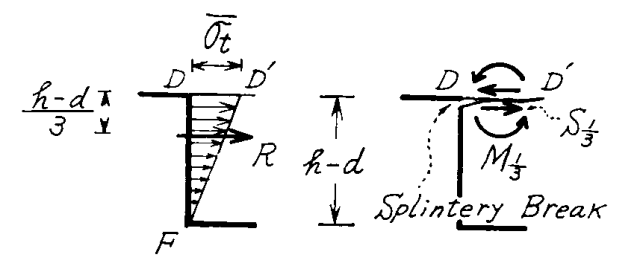

$R:$ Resultant Force

(a)

(b)

Fig. 5 Mechanism of Splintery Break at the End of Notched Portion, when the Depth of Notched Portion is two-thirds of the Beam Depth (欠 き込み部底面端における 割裂破壤のメカニズム 一欠き込み部のせいがはりせいの $2 / 3$ の場合）

次の通りで，いずれも $(d / h)$ と $(d / h)^{2}$ の関数である。 欠き込みせいがはりせいの $1 / 2$ の場合：

$$
\left.\begin{array}{l}
\bar{S}_{1 / 2}=\frac{6}{h} \cdot \frac{1-(d / h)}{\{1+(d / h)\}^{2}} M=1.33 \frac{M}{h} \\
\bar{M}_{1 / 2}=\left\{\frac{1-(d / h)}{1+(d / h)}\right\}^{2} M=0.111 M
\end{array}\right\}
$$

欠き込みせいがはりせいの $1 / 3$ の場合：

$$
\left.\begin{array}{l}
\left.\bar{S}_{1 / 3}=\frac{3}{h} \cdot \frac{1-(d / h)}{1-\frac{1}{4}(d / h)^{2}} M=1.13 \frac{M}{h}\right\} \\
\bar{M}_{1 / 3}=\frac{\{1-(d / h)\}^{2}}{\left\{1-\frac{1}{4}(d / h)^{2}\right\}} M=0.125 M
\end{array}\right\}
$$

ここに $h:$ 非久き込み部のはりせい $(\mathrm{cm})$

$d:$ 欠き込み部のはりせい $(\mathrm{cm})$

$M:$ 作用する曲げモーメント $(\mathrm{kg} \cdot \mathrm{cm})$

(4) (A)，(B) 両式を比較してみると，せん断力 $\bar{S} の$ 值と割裂モーメント $\bar{M}$ の值は，欠き込みせいが $1 / 2$ の 場合と $1 / 3$ の場合との間にそれほど大きな差がない。こ のことは終局曲げモーメント（破壊曲げモーメント）の 上で大差ないことを予想させるが，筆者等がさきに行な った実験 ${ }^{1)}$ の結果はその妥当性を立証している。これら の理論・実験両面からの解析を参考机する, はりの支 点以外の断面における久き込みに関する制限として「は りせいの $1 / 3$ 以上を欠き込んではならない」という考え 方には余り根拠がなく, 引張側に欠き込みを設ける場 合, はりせいの $1 / 2$ 程度まで久いても耐力上の危険はな いように思われる。この考え方の当否について読者のご 批評を仰ぎたい。

\section{Reference [参考文献]}

1）杉山英男，中田和夫：木質系のはりの曲げ耐力と岡性に 及ぼす欠き込みの影響について(続報)，日本建築学会論 文報告集第 200 号, 1972 年 10 月。 


\title{
THE MECHANISM OF THE REDUCTION OF BENDING STRENGTH OF WOODEN BEAM HAVING A NOTCH ON THE TENSION SIDE.
}

\author{
by Hideo SUGIYAMA*, Member of A.I.J.
}

\section{$\S 1$ Synopsis}

Author reported the experimental results on the influence of a notch upon the strength and stiffness of wooden beam subjected to bending ${ }^{1}$. In the above experiment, the longitudinal strain distributions were measured by the use of electrical wire strain gages attached at the specific points on a notched section and on the non-notched sections adjacent to the notch. In this paper the longitudinal strain distributions at the above-mentioned sections of each beam having a notch on the tension side are introduced and the discussion on the mechanism of the reduction of ultimate strength of wooden beam having a notch on the tension side is made by refering to the above test results.

\section{\$ 2 Longitudinal stress and strain distributions on and near the notched section}

The ordinary and the laminated wooden beams selected as the test specimens were loaded by the method shown in Fig. 1(b) in the previous report ${ }^{1}$. The longitudinal strain distributions were determined by the use of electrical strain gages attached to the test specimens as shown in Photo. 1 . It was assumed that the strain measured by the gage shows the strain at the mid-length of each gage. The vertical distributions of the longitudinal strain on the different sections at the bending moment at proportional limit and at one-half of above bending moment are plotted in Fig. $1(a) \sim(f)$ and Fig. 2 (a) $\sim(f)$ on the basis of the usual assumption that plane sections remain plane during the bending. Fig. 1 and Fig. 2 are the figures for the ordinary wooden beams and for the laminated wooden beams, respectively, both figures showing the results in which the ratios of notched depth to the non-notched depth are $1 / 3$ and $1 / 2$.

Specific sections of each beam to which electrical strain gages were attached were selected as follows, all the specific sections being subjected to pure bending moment.

(1) Three cross sections for one group : at midspan of the beam (middle point of notched portion) and at the cross sections $45 \mathrm{~mm}$ (notched portion) and $80 \mathrm{~mm}$ (non-notched portion) distant from the midspan.

(2) Four cross sections for the other group : at midspan of the beam (middle point of notched portion), and at cross sections $80 \mathrm{~mm}, 205 \mathrm{~mm}$ and $330 \mathrm{~mm}$ distant from midspan, these section being without notch.

The longitudinal strain districutions in the beam having a notch on the compression side were measured by the same method as that in case of a tension side notch, those showing the same tendency in the strain distribution, although the distribution shape is inverse to that in case of tension side notch.

It can be considered that strain distributions shown in Figs. 1 and 2 belong to elastic range and that, therefore, the stress-strain curves show straight line. Furthermore, assuming that the material posseses the same value of Young's modulus both for tension and compression, it can be considered that the longitudinal stress distributions across the depth of the beam shows the same type of shape as the corresponding longitudinal strain distribution.

Seeing Figs. 1 and 2, it can be found, in all the specific sections where electric strain gages were

* Prof. of Meiji Univ., Dr. of Engineering. 
attached, that the stress distributions the depth of the beam satisfy the condition of equilibrium in good approximation, in other words, that internal compression force is approximately equal to internal tension force. This fact indicates that the following three assumptions are appropriate.

(1) Plane section remains plane during the bending.

(2) Stress-strain curves are straight-line for both tension and compression.

(3) Young's modulus is same for both tension and compression.

The longitudinal stress distributions across the depth of the beam at the notched section and at the non-notched section near the notch are divided into two types as illustrated in Figs. 3(a) and 3 (b). Fig. 3(a) is for the condition that the notch ratio (the ratio of the notched depth to the non-notched depth) is $1 / 2$, while Fig. 3(b) for the notch ratio of $1 / 3$. Futher, it should be noted that the difference between the strain distributions at the specific sections in the ordinary and the laminated wooden beams is not found.

The longitudinal strain distributions in case of the notch ratio of $1 / 6$ are not introduced in this report, because the shapes of strain distributions show wide variation and, on the other hand, the condition of equilibrium of force on the cross section is not always satisfied. This observation indicates that the vertical distributions of the longitudinal strain and stress at the non-notched cross section adjacent to the notched section are very complex and complicated, and different case by case.

\section{$\$ 3$ Analysis of results $I$ (When the notched ratio is $1 / 2$ )}

A. Assumption

(1) The cross section is rectangular, $b$ and $h$ being the width and the depth, respectively.

(2) In Fig. 3(a), the range between points $E$ and $F$ is not stressed and point $E$ is located at the center of $E F$. namely, $\zeta=(h+d) / 2$.

B. Equilibrium of moment at the notched cross section AB.

Equation (1) is derived from the equilibrium of moment at the cross section $A B$, where

$\sigma_{c}$ : see Fig. 3(a)

$Z_{n}:$ Section modulus

$M$ : Bending moment acting on the cross section $\mathrm{AB}$

$d:$ depth of the notched cross section $\mathrm{AB}$

C. Equilibrium of axial force at the non-notched cross section CDE.

Equations (2) and (3) are derived from the assumption that plane section remains during the bending and from the condition of equilibrium of axial force at the cross section CDE, respectively. The meanings of symbols in eqs. (2) and (3) are shown in Fig. 3(a).

Eq. (4) is derived from eq. and (3) substitution of eq. (4) into eq. (2) gives eq. (5). Further, substituting eq. (5) into eq. (2), eq. (6) is given.

D. Equilibrium of moment at the non-notched croess section CDE.

Considering the equilibrium of moment at the cross section CDE, eq. (7) is given, where the symbols are shown in Fig. 3(a).

Substitution of eqs. (5) and (6) into eq. (7) gives eq. (8).

By substituting eqs. (1) and (8) into eq. (6), $d \sigma_{c}$ is obtained as eq. (9).

Letting $d M=0$, when subjected to pure bending, as in this investigation, eqs. $\left(8^{\prime}\right)$ and $\left(9^{\prime}\right)$ are derived.

E. Stress condition at the bottom corner of the notch.

Let us discuss the stress condition at the bottom corner of the notch (point D) by neglecting local stress concentration.

On the horizontal plane $\mathrm{DD}^{\prime}$ adjecent to $\mathrm{D}$, shear force $\bar{S}_{1 / 2}$ expressed by eq. (10) and moment $\bar{M}_{1 / 2}$ given by eq. (11) act simultaneously as illustrated in Fig. 4(b).

The moment $\bar{M}_{1 / 2}$ causes splintery break along the plane $\mathrm{DD}^{\prime}$, namely splitting off the upper and the lower parts of the plane $\mathrm{DD}^{\prime}$. The moment like $\bar{M}_{1 / 2}$ is called "splitting moment" hereinafter. 
When a notch is located on the compression side, shear fore acts along the horizontal plane like the plane $\mathrm{DD}^{\prime}$, while the moment corresponding $\bar{M}_{1 / 2}$ acts on the above horizontal plane in the direction restricting the splitting, namely in the inverse direction to the splitting moment.

The reason why the proportional limit load and the ultimate load in the wooden beam having a notch on the compression side is larger than those in the beam having a notch on the tension side, will be understood by the above explanation.

\section{$\S 4$ Analysis of results II (When the notched ratio is $1 / 3$ )}

A. Assumption

Same as the assumptions in $\S 3 \mathrm{~A}$. The stress distribution between points $\mathrm{D}$ and $\mathrm{F}$ is assumed as, I straight line as illustrated in Fig. 3(b).

B. Equilibrium of moment at the notched cross section AB.

Eq. (1) is also applicable to this case, where the meaning of $\sigma_{c}$ is shown in Fig. 3(b).

C. Equilibrium of axial force at the non-notched cross section CDF.

From the same procedures as $\$ 3 \mathrm{C}$, eqs. (12),(13) and (14) are derived, where the meanings of symbols is given in Fig. 3(b).

D. Equilibrium of moment at the non-notched cross section CDF.

The condition of equilibrium of moment at the cross section CDF is expressed as eq. (15).

Substitution of eqs. (13) and (14) into eq. (15) gives eq. (16).

Substituting eqs. (1) and (16) into eq. (14), $d \sigma_{c}$ is given by eq. (17).

When subjected to pure bending, eqs. $\left(16^{\prime}\right)$ and $\left(17^{\prime}\right)$ are given by substituting $d M=0$ into eqs.. (16) and (17).

E. Stress condition at the bottom corner of the notch.

Shear force $\bar{S}_{1 / 3}$ expressed by eq. (18) and splitting moment $\bar{M}_{1 / 3}$ expressed by eq. (19) act along. the horizontal plane $\mathrm{DD}^{\prime}$ as shown in Fig. $5(\mathrm{~b})$.

$\S 5$ Stress condition at the bottom corner of the notch at failure due to splintery break. Conclusions.

Shear forces $\bar{S}$ and splitting momentf $\bar{M}$ acting on the plane $\mathrm{DD}^{\prime}$ are derived in $\S 3 \mathrm{E}$ and $\S 4 \mathrm{E}$. Substituting the actual value of the depth on the notched section into the above equations, the following results are obtained.

(1) When the notch ratio is $1 / 2(d=h / 2)$

$$
\left.\begin{array}{l}
\bar{S}_{1 / 2}=\frac{4}{3} \cdot \frac{M}{h}=1.33 \frac{M}{h} \\
\bar{M}_{1 / 2}=\frac{1}{9} \cdot M=0.111 M
\end{array}\right\}
$$

where $M$ is the bending moment at the notched cross section and $h$ is the depth of non-notched cross section.

(2) When the notch ratio is $1 / 3(d=2 h / 3)$

$$
\left.\begin{array}{l}
\bar{S}_{1 / 3}=\frac{9}{8} \cdot \frac{M}{h}=1.13 \frac{M}{h} \\
\bar{M}_{1 / 3}=\frac{1}{8} \cdot M=0.125 M
\end{array}\right\}
$$

Observing and comparing eqs. (20) and (21), it can be found that the difference between the values of $\bar{M}$ in both equations is not large, although $\bar{M}_{1 / 3}$ is, of course, slightly larger than $\bar{M}_{1 / 2}$ and that the values of $\bar{S}$ in eqs. (20) and (21) show good agreement.

These important tendency was already pointed out in the previous paper ${ }^{1 /}$ from the experimental point of view (See Fig. 3 in the previous paper ${ }^{1)}$ ). It can be said that the fact pointed out in the: experiment has been theoretically demonstrated in this paper.

Although it is provided in "Structural Standards in Architectural Institute of Japan" that the notched depth on the notched section should be less than one-third the depth of the non-notched 
section, the author's experimental investigation backed up by theoretical analysis suggests that the large notching of the depth of non-notched cross section is not always dangerous, but may be allowed structurally under the limitation that the notched depth should be not more than one-half of the nonnotched depth if design requests eagerly a big notch.

\section{Reference :}

1) Sugiyama, H. and Nakada, K. Influence of notch on the strength and stiffness of ordinary and laminated wooden beams subjected to bending, Transactions of A.I.J., No. 200, Oct. 1972. 


\section{TRANSACTIONS OF THE ARCHITECTURAL \\ INSTITUTE OF JAPAN}

\section{S Y N O P S I S}

U.D.C. 624.011.1

THE MECHANISM OF THE REDUCTION OF BENDING STRENGTH

OF WOODEN BEAM HAVING A NOTCH ON THE TENSION SIDE

(See Page 7)

by HIDEO SUGIYAMA, Prof. of Meiji Univ, Member of A.I.J.

U.D.C. 624.012.4:624.042

\section{KINEMATIC ANALYSIS OF CONCRETE MEMBERS UNDER COMBINED STRESSES}

(Part 2-1) A Stochastical Study on the Shear Strength of the

Reinforced Concrete Members under Combined Stresses

-Bending Moment, Shearing Force and Axial Force- Case of

Bending Moment and Shearing Force.

by Dr. YASUYOSHI SUENAGA, Professor of Yokohama National Univ, and RINTARO ISHIMARU, Assistant of Yokohoma National Univ. Members of A.I.J.

The shear strength and shearing-failure mechanism of reinforced concrete members under combined stresses is not made clear theoretically. Experimental 979 values, selected from many references are classified in different loading systemy, analyzed stochastically. And population on the shear strength of reinforced concrete beams is obtained. and it is discussed of the correlation between these populations and "Reinforced Concrete Structure Standard of A.I.J." 